\title{
MOOC Camps: Stories to Tell, Lessons to Share
}

\author{
Rey A. Mangarin ${ }^{1}$, Rebecca C. Sagot ${ }^{2}$, Wendie D. Cutillon ${ }^{3}$ \\ ${ }^{I}$ Faculty, The University of Mindanao (Panabo) \\ ${ }^{2}$ Faculty, The University of Mindanao (Professional Schools) \\ ${ }^{3}$ Master Teacher I, DepEd Davao del Norte \\ DOI: https://dx.doi.org/10.47772/IJRISS.2021.5337
}

\begin{abstract}
This study explores the different unique experiences of different MOOCers in the Division of Davao del Norte. Data were gathered throughin-depth interviews andfocus group discussions while thematic analysis was used to generate knowledge on what were the unique experiences with strong moral lessons of these teachers who engaged in MOOC Camps. Moreover, this study also narrates the challenges and struggles, and personal and professional barriers on the completion of MOOCs and how these addressed the challenges encountered by MOOCers by equipping themselves with initiative, sense of responsibility, collaboration, belongingness, and enhanced teaching-learning competence. Nine significant stories with exceptional lessons were found and these are: For better or for Worst, Crossing Borders, Breaking Walls, The Highland Victory, Connecting the Unconnected, Friendship Goals, Leading as Models, Siblings Reunited, and M-Pop and C-Pop Phenomenon.This study revealed that MOOC experiences have significantly contributed to public school teachers' holistic development processes with a long term effect and that massive open online courses are good venues for professional training of teachers.
\end{abstract}

\section{I.INTRODUCTION}

\section{Background of the Study}

I $\mathrm{n}$ this digital era where information and facts are wide and immeasurable and learning comes in various forms, teachers are in the bank of responsibility to update them and get ahead over the learners. Experiences as they say are the best teachers and it is through this research that teachers' experiences in the Massive Open Online Course are good points of reflection and reference for innovative learning strategies and design of learning avenues. Tracing the long term effects of online courses is a very good basis of redeveloping other online courses based on strengths and weaknesses of the current and previously completed courses.

Although massive open online courses (MOOCs) are designed to be stand-alone online courses, their implementation to the participants are not really meant to be just like very independent by nature but instead, they have to be expanded to the space of possibilities for blended course designs, combination of online and meet-ups, in order that participants will be able to successfully complete the courses offered. The innovated MOOC Camps which leveraged a MOOC course and platform for lecturing, grading, and discussion, enabled the facilitators to lead the participants incourse in a topic much desired, leading the camps to be effective (Bruff, 2013).
Participants in Massive Open Online Course had experiences on the instructor presence and participation, instructor responsiveness and feedback, student-to-student interaction facilitated by instructor, deep thinking, reflection and learning from others, connections to own experiences, course organization, clear expectations, and course content. The experiences from participants of online courses offer rich, descriptive narrative that provides educators with valuable information that should assist faculty in developing, constructing, and implementing engaging online courses. The stories generated in the study augment existing studies that provide quantitative data on learners' experience in online courses. Also, the stories provide concerned educational leaders with significant information regarding engaging online courses that can guide them in constructing appropriate and necessary support for teachers and other personnel in their participation to online courses.

There were many research studies about the importance of MOOCs, how each course work out, the system that each online course follows, and even the documentation of how effective the MOOCs are. But seldom one can read stories of participants with both struggles and victories with coparticipants of MOOC Camps. This research is a documentation of different stories identified during the MOOC camps. Experiences of participants are good sources of learning which every learner, especially the adult learners, can use in reflecting through the language learning process. Moreover, this narrates the different significant human experiences with valuable lessons coming from the participants and from the people behind MOOC camps.

\section{Research Design}

In the light of qualitative approach, this examined the social phenomenon, concerns, and themes. The appropriateness of choosing qualitative approach is because qualitative research seeks evidence that concerns the types of factors that influence the way human beings think and react to their surroundings. Qualitative approach is for researcher to collect data by observation and the approach allows researcher to be able to repeat the observation mode in order to verify or refute the finding (Henson, 2012).Particularly, this utilized phenomenologybecause this explains the lived experiences of teachers who completed the Massive Open Online Courses.Phenomenological study best suited as the research design because this is a phenomenon that is observed in the 
academic setting today. Raagas (2010), as cited by Tagadiad (2012), emphasized that this design would look into the multiple perspective of the situation and make generalizations of what is something like. In this design, it depends almostexclusively on lengthy interviews with carefully selected sample participants.

\section{Research Locale and Participants}

The study took place in Davao del Norte Division, Davao del Norte, Philippines 8112. This study was documented since the beginning that MOOC Camps had started in the Division of Davao del Norte. The completion of this research was through the gradual weaving of different knowledge generated in every round of MOOC Camps.

There were two sets of participants in this study, the first were 24 MOOCers and the other set is composed of eigthMOOCers.

For the 24 purposively chosen participants of this study, these were teachers who were able to finish the massive open online courses headed by the Education Program Supervisor of the Division of Davao del Norte.

Table 1: First Set of Participants of the Study

\begin{tabular}{|l|l|}
\hline PARTICIPANT & PROFILE \\
\hline IDII\#001 (2 Informants) & Married Couples \\
\hline IDII\#002 (3 Informants) & $\begin{array}{l}\text { MOOCers Abroad and Outside } \\
\text { Davao del Norte }\end{array}$ \\
\hline FGDI\#003 (4 Informants) & $\begin{array}{l}\text { Private, Higher Education, } \\
\text { Catholic School, and Muslim } \\
\text { Representatives }\end{array}$ \\
\hline IDII\#004 (1 Informant) & MOOCer from Mountain Schools \\
\hline IDII\#005(1 Informant) & $\begin{array}{l}\text { MOOCer without Internet } \\
\text { Connections }\end{array}$ \\
\hline FGDI\#006 (5 Informants) & Group of Friends \\
\hline IDII\#007 (1 Informant) & School Heads \\
\hline IDII\#008 (2 Informants) & Sibling MOOCers \\
\hline FGDI\#009 (5 Informants) & Team Leaders \\
\hline
\end{tabular}

Table 2: Second Set of Participants of the Study.

\begin{tabular}{|c|c|}
\hline Participant & Profile \\
\hline MOOCer\#001 & $\begin{array}{c}\text { Mathematics Teacher and Mathematics Quiz } \\
\text { Coach }\end{array}$ \\
\hline MOOCer\#002 & Research Teacher \\
\hline MOOCer\#003 & Elementary School Teacher \\
\hline MOOCer\#004 & English Language Teacher \\
\hline MOOCer\#005 & Reading Coordinator \\
\hline MOOCer\#006 & $\begin{array}{c}\text { Dance Specialist Teacher in Special Program in } \\
\text { the Arts }\end{array}$ \\
\hline MOOCer\#007 & Filipino Language Teacher \\
\hline MOOCer\#008 & Science Teacher \\
\hline
\end{tabular}

Data Gathering Procedure and Instrument
An interview guide questionnaireon exceptional stories and overcoming challenges was used in the study. In the gathering of data, participants were undergonein-depth interview. Each participant was given a letter and an informed consent prior to the interview process. After the schedule has been set, the identified participants underwent an in-depth interview that each shared stories regarding their experiences. The second data gathering procedure was focus group discussion where the participants interviewed were invited during a small dinner gathering and shared their stories on their MOOC experiences. The researcher facilitated the discussion. Audio recorder was used to document their responses. Transcription was done after the gathering of data. The transcribed interview script was then written and translated for data analysis procedure.

\section{Exceptional Stories in DavNor MOOC Camps}

There were different experiences considered exceptional stories during the MOOC Camps. These nine significant stories with exceptional lessons were For better or for Worst, Crossing Borders, Breaking Walls, The Highland Victory, Connecting the Unconnected, Friendship Goals, Leading as Models, Siblings Reunited, and M-Pop and C-Pop Phenomenon. Further, the following enabled the MOOCers to successfully complete the online course: Initiative, Sense of Responsibility, Collaboration, Belongingness, and Enhanced Teaching-learning Competence.

Table 4: Exceptional Stories in DavNor MOOC Camps

\begin{tabular}{|c|c|}
\hline THEMES & CORE IDEAS \\
\hline $\begin{array}{l}\text { For Better or for } \\
\text { Worst }\end{array}$ & $\begin{array}{l}\text { The completion of online course is indeed tough but } \\
\text { having a partner both during the course and even in } \\
\text { extending time for the course in home, the course } \\
\text { flows smoothly. }\end{array}$ \\
\hline Crossing Borders & $\begin{array}{l}\text { MOOC Camps are not only exclusive for those who } \\
\text { can attend personally, the camps serve both local, } \\
\text { regional, national, and even international participants } \\
\text { and see with each other through any channel. }\end{array}$ \\
\hline Breaking Walls & $\begin{array}{l}\text { MOOC Camps are not exclusive, everybody is } \\
\text { welcome to learn and be an agent of learning. } \\
\text { Religions and sectors do not matter. }\end{array}$ \\
\hline $\begin{array}{l}\text { The Highland } \\
\text { Victory }\end{array}$ & $\begin{array}{c}\text { Geographical location is not a hindrance to be a part } \\
\text { of the MOOC camps. }\end{array}$ \\
\hline $\begin{array}{l}\text { Connecting the } \\
\text { Unconnected }\end{array}$ & $\begin{array}{l}\text { The absence of internet connections does not hinder } \\
\text { the completion of online courses and attendance to } \\
\text { MOOC camps. }\end{array}$ \\
\hline Friendship Goals & $\begin{array}{l}\text { MOOC Camps serves as avenue for bonding and } \\
\text { friendship building among group of friends. }\end{array}$ \\
\hline Leading as Models & $\begin{array}{l}\text { Teaching courses through online are also venue for } \\
\text { learning among school heads. }\end{array}$ \\
\hline Siblings Reunited & $\begin{array}{l}\text { Sisters and siblings were brought together and } \\
\text { worked together during MOOC camps. }\end{array}$ \\
\hline M and C Pop & $\begin{array}{c}\text { MOOC and Coursera has been popularized by } \\
\text { participants not only within Davao del Norte but also } \\
\text { outside. }\end{array}$ \\
\hline
\end{tabular}

The first story was the experience of married couple who together joined and successfully completed the online course. With the support, in all forms, to each other, they were able to create a beautiful experience during the MOOC camps. 
Further, it's a matter of the support system that will make the participation of the MOOCer successful.

IDII\#001(Wife) said: Coursera is like marriage. In troubles and difficulties, we have each other. And in the moment that we were able to accomplish things regarding the course, we celebrate together.

IDII\#001 (Husband) said: It's a nice feeling to have always somebody to share with even in the academic endeavor. She has proven that she will always be there for better (achievement) and worst (difficulties) during the course. She's really my partner not just in life but even in learning.

The second story was the experience of MOOCers from abroad and from outside Davao del Norte. The camps indeed welcome participants like they belong in one region.

IDII\#002 (MOOCer from Abroad) said: Distance is indeed not a hindrance to participate MOOC Camps in the Davao del Norte. Through Skype, I was able to join the gatherings and meet-ups though most of the times internet connection was really a problem. However, it's indeed a pleasure to be a part even not being with them in actual presence.

IDII\#002 (MOOCer from Outside DavNor) said: The feeling when you are accepted by group of MOOCerswhereinfact I don't belong in this division. However, the invitation and the beauty that they are willing to accept you for the camp crossed the borders.

IDII\#002 (MOOCer from Outside DavNor) said: I love how DavNor accepted me to be a part of the camp sharing their best practices. I went home bringing all those beautiful learnings and share them with teachers within our division.

The third story was the experience of participants from different sectors and religions. Similar stories and lessons were shared from all participants regardless if they came from private schools, college institutions, Catholic schools, or even Muslim by religion.

FGDI\#003(From Private School) said: I never felt inferiority from teachers from public schools. By joining Coursera, I felt I am already a part of the huge group of public school teachers.

FGDI\#003 (From Tertiary Institution) said: Joining the camps helped me realized the connection between the basic education and tertiary education. The experienced allowed me to synthesize and come up with a strategic plan in performing my tasks in college institutions. Further, it's a nice feeling to have learnt with amazing people in the Department of Education because practices I learnt and linkages I established helped me more in teaching college students.
FGDI\#003 (From Catholic School) said: Religious beliefs are neglible and were not hindrances in collaborating with other participants. In fact, religion has been used during discussion as a very important topic for learning and not for barrier.

FGDI\#003 (From a Muslim Participant) said: Religious affiliations provide the discussion a rich source of sharing ideas especially in terms of practices, beliefs, traditions, and culture. In fact, by being a Muslim, other participants have been so interested to learn with me and I felt so gratified whenever we pray in different ways but united during the camps.

The fourth story was the experience of participant from highland, where school and most of the times in a week are in a far flung areas of mountain. Despite the geographical location that sometimes the participant was unable to access the MOOC camp, it has never made him give up from the course.

IDII\#004 (MOOCer from Highland) said: It is very hard on my part doing and completing the course especially that I am assigned in a very far barangay where all I am with are indigenous people. However, I find ways in making up with the completion of the course. I traveled the mountains and even surpassed greater heights just to earn the certificate.

The fifth story was the experience of participant without internet connection, not even in school where he is assigned. Doing online course requires internet connection, basically, but despite this constraints, the MOOCer was able to complete by making night as day and even asking help from those with internet connections.

IDII\#005 (MOOCer without Internet Connection) said: It's like I am in a battlefield armless. Internet connection is indeed an essential requirement to do the online course but I don't think that without it one cannot succeed the course. It's just looking for an opportunity in a difficulty. So every night, I went to the town where electricity, computers, and internet connections are available. I do it more often dawn because connections are strong. Thanks God I for other participants who offered assistance in times I cannot make it due to uncontrolled factors.

The sixth story was the experience of group of friends and their goal to finish the two online courses together. Having a relationship prior to the course was indeed of great help for the participants because it provides them assurance that support system is available whenever help is necessary.

FGDI\#006 (Math Teacher) said: Together we stand, and divided we won't allow to fall in the online course. This was the principle I always assure with them.

FGDI\#006(MAPEH Teacher) said: Coursera time was indeed jokes time for us. We learnt and easily shifted 
from serious discussions and learning action cells into gags and jokes. This made our learning journey and friendship worth the cherish.

FGDI\#006 (Math Teacher) said: I experienced the best and the potentials of my sissies through MOOC and Coursera. They were sharing their resources and even time with me.

FGDI\#006 (English Teacher) said: It's (MOOC Camp) a good avenue to share the gift of learning to your sister not blood-related, my sissies!

FGDI\#006 (English Teacher) said: MOOC time is our bonding time, Coursera time is sissies time!

The seventh story was the experience of a school head. Even school management and leadership competence can be nurtured by learning the teaching-learning process especially in the language learning. The experience of the school administrator provides a clearer framework that leadership is indeed taking the first step so the rest of the teachers will follow.

IDII\#007 (School Head) said: It's not because I am the leader, I have to command them to engage in the course which is very new to them. Instead, I have to test the water for them to enjoy it. Like, I don't need to force them grow but lead them and inspire them that even I as a school manager and an instructional leader, can grow from an online courses intended for teachers. So why not engage if the courses were intended for them. I serve as inspiration, then my teachers enrolled the next round.

The eighth story was the experience of siblings. It is indeed a truism that when siblings grow, they sometimes work together and enjoy the things they used to do and they were used to stay. Others have resided a far places and live separate independent lives with lesser communications. But it is through the camp that siblings were reunited and were able to enjoy the learning activities together having shared both experiences when they were still young and when they were in the online course.

IDII\#008 (Sibling 1) said: I was so happy that we have made it again together through online course. We have lived and seldom see each other due to busy work but with the camps, we shared quality time with each other.

IDII\#008 (Sibling 2) said: When we were working the assignments and tasks of the Coursera, I was able to remember how she (my ate) taught me how to read and do my assignments when we were still in elementary school years. It's like we have traveled in the past.

The ninth story was the experience of designated team leaders and their goal to lead the rest of the MOOCers.It was found out that M-Pop, MOOC Populairty and C-Pop, Coursera Popularity, went viral all over the Division of Davao del Norte and even outside. People always ask what's Coursera and what's MOOC since only few have underwent online courses. When MOOCers talk Coursera and MOOC, it seems they were only the ones who could understand the terms.

FGDI\#009 (Team Leader 1) said: It's a pressure on the part of being designated as a leader because there are also other participants who are far well better than me, I supposed. But it is the trust that I am holding and the inspiration that I believe I can do the entrusted task to me. Though sometimes hard, I was able to manage my team. I just love listening when all of the times they utter are Coursera and MOOC. That made others wonder what are those two words referring to?

FGDI\#009 (Team Leader 2) said: I sometimes feel down when one participant is about to give up or will no longer communicate me and especially when the participant is no longer replying my text. But I have overcome all the challenges though there were very few that can only be counted in my fingers who really gave up, many were so grateful and happy with the service I offered. That made me fulfilled over the minute failure I felt especially when Coursera and MOOC became a phenomenon in the municipality.

FGDI\#009 (Team Leader 3) said: Having a large group of participants entrusted and who trusted me to lead them is quite hard on my part to who shall I prioritize. But since majority understand and has the helping hands even not designated team leaders, I was able to minimize the burden. Actually, the participant's leadership for themselves is a victory on my part that I have led them to lead. It's more than a victory, indeed, an idea mark that Coursera and MOOC were popularized by teachers.

FGDI\#009 (Team Leader 4) said: I often feel pressured and down whenever I cannot attend the needs of my team. Sometimes I feel so guilty but at the end, everything went well. And everything went viral.

FGDI\#009 (Team Leader 5) said: The success of my team in completing the course is indeed a good determinant that I have led them successfully. And making MOOC and Coursera talk of the town made me more than feel the success.

Coping Mechanisms of MOOCers on the Challenges in Camps

During the course period, MOOCers encountered several issues and challenges which serve as barriers for them to complete the online course. However, there were coping mechanisms employed by the participants in overcoming the challenges during the course which are initiative, sense of responsibility, collaboration, belongingness, and teaching competence.

Table 5: Mechanisms on Coping with the Challenges in MOOC Camps 


\begin{tabular}{|c|c|}
\hline THEMES & CORE IDEAS \\
\hline Initiative & $\begin{array}{c}\text { Participants have to initiate of their own and } \\
\text { find ways to overcome the challenges. } \\
\text { Solution starts within one's self. }\end{array}$ \\
\hline $\begin{array}{c}\text { Sense of } \\
\text { Responsibility }\end{array}$ & $\begin{array}{c}\text { The feeling of being accountable for learning } \\
\text { and leaning of other participants innites the } \\
\text { flame of completing the course and } \\
\text { overcoming the challenges. }\end{array}$ \\
\hline Collaboration & $\begin{array}{c}\text { With unity, helping hearts, cooperation, and } \\
\text { collaboration, MOOCers were able to } \\
\text { complete the online courses successfully. }\end{array}$ \\
\hline Belongingness & $\begin{array}{c}\text { The treatment of other participants help the } \\
\text { MOOCer overcame the challenges. }\end{array}$ \\
\hline Teaching & $\begin{array}{c}\text { The learnings from the actual teaching inside } \\
\text { the classroom enabled the teachers to answer } \\
\text { and address the problems during the course } \\
\text { Competion. }\end{array}$ \\
\hline
\end{tabular}

The first coping mechanism employed was the initiative. It plays a vital role to command one's own self to work for the responsibilities and accountabilities on hand. Without initiative to find ways, to look for means, and to innovate strategies in completing the tasks in MOOC, participants will not be able to finish the course successfully.

FGDI\#009 (Team Leader 1) said: It's a matter of giving the ideas on how to do it. Then the rest will be done by the team members to the extent of how will they do it. It's just the initiative to undertake the things necessary.

FGDI\#009 (Team Leader 2) said: The absence of a team leader sometimes led them to take initiative to do what they are supposed to be done...it's initiative.

FGDI\#009 (Team Leader 3) said: When you give them the ways, they will just wait and be used to receiving of the ways, but when you give them the time, swear, they were able to make use of that time as initiative.

IDII\#002 (MOOCer from Abroad) said: I just do set up my Skype to be a part of the meet ups because no one will make it for me. It's a matter of taking initiative.

IDII\#002 (MOOCer from Outside DavNor) said: The time when I have to travel to Davao del Norte and have to be with them, with my own course and initiative.

The second coping mechanism employed was the sense of responsibility. When participants feel their responsibility for themselves, for the group, for their learning, and for the opportunity given to them, they would be able to complete the task given. Sense of responsibility indeed plays a vital role why MOOCers completed the courses successfully.

FGDI\#009 (Team Leader 4) said: Though it's difficult on my part to lead the participants, I feel more honored to have this task. With this, I always have in my mind the responsibility and put it in my heart.

IDII\#001 (MOOCer Husband) said: I don't only have the responsibility as a husband but as a co-learner of my wife.
FGDI\#006 (Math Teacher) said: I need to share the opportunity to my sissies for them to experience the beauty of learning, though hard from the beginning. But the moment they went through the chance of learning I shared with them, the feeling of need to share with them has been replaced with the feeling of I must help them.

The third coping mechanism employed was collaboration. This is the most sold out mechanism among the rest. Every MOOCer was able to complete the course because of the support system received from co-participants and leaders.

FGDI\#009 (Team Leader 4) said: They (my team members) always count on what can I assist with them.

IDII\#001 (MOOCer Wife) said: I am always counting in my husband especially in the course of technology manipulation.

FGDI\#006 (English Teacher) said: I have my sissy who's expert in ICT, so no worries if I encountered technical problems.

IDII\#004 (MOOCer from Highland) said: There were always MOOCers who entertained me when I went down to the town just to finish the task. Sometimes, I just leave my output to some MOOCers before I went to my station up in the mountain and asked them to please send it before the deadline.

IDII\#004 (MOOCer without Internet Connection) said: I sometimes feel so overwhelmed and proud whenever many MOOCers offered a lot of broadband and laptops and even invited me to stay at their homes offering all the internet resources just for me to finish the tasks.

FGDI\#006 (Math Teacher) said: I have lost my hope to finish the course because I was sick and admitted and even lost my files and account. Thanks God there were many who visited me, or I am not just sure if they visited me because they are worried about me or they are worried if I am not able to finish the course. Hahahhahaha. Nevertheless, there were a lot of them who helped me retrieve and manipulate the technology while I was in bed in the hospital. I felt so happy and loved that day.

The fourth coping mechanism employed was the sense of belongingness. When participants feel as if they really are part of the group, their confidence was enhanced and they were able to take initiatives to work. So, it is very important that letting others feel they belong enhances the chance of completing the course.

IDII\#002 (MOOCer from Abroad) said: Distance is indeed not a hindrance to participate MOOC Camps in the Davao del Norte. Through Skype, I was able to join the gatherings and meet-ups though most of the times internet connection was really a problem. However, it's indeed a 
pleasure to be a part even not being with them in actual presence.

IDII\#002 (MOOCer from Outside DavNor) said: The feeling when you are accepted by group of MOOCerswhereinfact I don't belong in this division. However, the invitation and the beauty that they are willing to accept you for the camp crossed the borders.

IDII\#002 (MOOCer from Outside DavNor) said: I love how DavNor accepted me to be a part of the camp sharing their best practices. I went home bringing all those beautiful learnings and share them with teachers within our division.

FGDI\#003 (From Private School) said: I never felt inferiority from teachers from public schools. By joining Coursera, I felt I am already a part of the huge group of public school teachers.

FGDI\#003 (From Tertiary Institution) said: I forget I am a college instructor when I am with the Department of Education teachers. It drives me like we are in the same agency and nothing's so different.

FGDI\#003 (From Catholic School) said: The very structured tradition before learning has been adapted and the mass of the Catholic has been accepted by those who are non-Catholic especially during the time of giving thanks for the victory we had. That brings the sense of belongingness.

FGDI\#003 (From a Muslim Participant) said: The way I dress up, the way I act, and the way I learn do not make a difference among most of the Christians. MOOC camps make me feel accepted with the rest.

The fifth coping mechanism was teaching competence. The lessons generated from experiences in the actual classroom teaching were very useful in completing the task. Hence, the years of experience generates competence in teaching, those experiences were used to answer questions and even in the making of outputs submitted. It's really an advantage being a teacher in finishing the online course.

IDII\#007 (School Head) said: It's both my experiences in teaching and management that helped me answered the questions and made my outputs submitted worth the higher ratings.

IDII\#008 (Sibling 1) said: Because we're both teachers with my sibling, we get along and we agreed to use what we have learnt and used to do in the school to answer the activities and make outputs required basen on teaching experience.

FGDI\#009 (Team Leader 1) said: It's just like treating the participants you are leading like your students. Hahahahaha. Understand and care for their learning, that's the secret.

\section{CONCLUSION AND RECOMMENDATION}

The Department of Education is highly recommended to select, identify, and recommend online courses that will address the needs of the participants. School administrators are encouraged to lead the engagement of online courses among teachers for professional and holistic enhancement and encourage other professionals and people who can be a support system of the target participants to be a part of the course. Teachers are also recommended to engage themselves in different available online courses so that their needs and demands in teaching will be addressed. This research is highly recommended for other researchers as reference for further and deeper exploration through different research approaches other than this manner.

Coming up with this research is indeed a task worth the reference. Findings regarding the exceptional stories draw vital lessons and moral reflections on the experiences of diverse people coming up in one event.Understanding and putting one's self in the experience of the participants will enable everyone to synthesize how online courses provides both the struggles and strengths which will be of great help in making online courses more simplified for the service providers and course designers. Also, the impacts on the different significant stories of participants which were influenced by their experiences in online courses will be of great bases for future researchers to explore more and evaluate the pros and cons of online courses. All in all, this research will be of great help to future researchers to identify the strengths and weaknesses of online courses and come up with another research with addressed problems.

\section{REFERENCES}

[1] Bruff, D. O., Fisher, D. H., McEwen, K. E., \& Smith, B. E. (2013). Wrapping a MOOC: Student Perceptions of an experiment in blended learning. Journal of Online Learning and Teaching, 9(2), $187 . \quad$ Retrieved from https://search.proquest.com/docview/1500421376?accountid=3125 9

[2] Canney, C. (2015). Elements that affect student engagement in online graduate courses (Order No. 3702588).Available from ProQuest Central. (1682465830). Retrieved from https://search.proquest.com/docview/1682465830?accountid=3125 9

[3] Henson, R. (2016). Qualitative Research: World of Reality Dissections. Quezon City: Mutya Publisihing House.

[4] Milligan, C., Littlejohn, A., \&Margaryan, A. (2013). Patterns of engagement in connectivistMOOCs. Journal of Online Learning and Teaching, 9(2), 149. Retrieved from https://search.proquest.com/docview/1500422899?accountid=3125 9

[5] Tagadiad, C. (2012). A Qualitative Inquiry on Relational Dialectics Among Employees in Higher Education. Dissertation. UIC. Davao City 